\title{
Nanotechnology applications in ophthalmology: An update
}

\section{Aplicaciones de la nanotecnología en el campo de la oftalmología: ¿dónde estamos?}

\author{
Marcela Gómez-Garzón ${ }^{1}$, M. Alejandra Martínez-Ceballos ${ }^{1 *}$, Arley Gómez-López ${ }^{1,2}$ and \\ Adriana Rojas-Villarraga ${ }^{1,2}$ \\ ${ }^{1}$ Research Division; ${ }^{2}$ Research Institute. Fundación universitaria de ciencias de la salud (FUCS), Bogotá, Colombia
}

\begin{abstract}
Nanotechnology is a discipline that focuses on the study, processing, and application of several materials, devices, and functional systems, controlling matter at the nanoscale. Nanomedicine refers to its applications for the diagnosis, treatment, prevention and monitoring of different diseases. Topical drug dosage forms for eye conditions must travel a great distance and overcome several eye barriers to reach the posterior segment of the eye, leading to minimum levels of medication. This review focuses on the therapeutic systems for eye diseases based on nanotechnology, emphasizing the barriers that affect the administration of ocular drugs and eye diseases and nanosystems used for their management. The perspective of nanotechnology and the challenges in the treatment and diagnosis of eye diseases are summarized, to provide information and new ideas for implementing treatments and developing management systems for intractable eye diseases.
\end{abstract}

Key words: Ophthalmology. Nanotechnology. Nanomedicine. Nanoparticles.

\section{Resumen}

La nanotecnología es una disciplina que se centra en el estudio, procesamiento y aplicación de diversos materiales, aparatos y sistemas funcionales, y controla la materia a nanoescala. La nanomedicina hace referencia a sus aplicaciones para el diagnóstico, tratamiento, prevención y seguimiento de diferentes enfermedades. Los medicamentos que se administran a través de gotas para los ojos deben viajar una gran distancia y evitar varias barreras oculares para llegar al segmento posterior del ojo, lo que lleva a niveles mínimos de medicamento. Esta revisión se centra en los sistemas terapéuticos para enfermedades oculares basados en nanotecnología, y hace énfasis en las barreras que afectan la administración del fármaco ocular y en las enfermedades oculares y los nanosistemas utilizados para su manejo. Se resume la perspectiva de la nanotecnología y los desafíos existentes en la terapia y el diagnóstico de las enfermedades oculares con miras a proporcionar información y nuevas ideas para implementar tratamientos y desarrollar sistemas de manejo de enfermedades oculares intratables.

Palabras clave: Oftalmología. Nanotecnología. Nanomedicina. Nanopartículas.

Correspondence:

*María Alejandra Martínez-Ceballos

FUCS, Cl. 10 \#18-75 Date of reception: 01-03-2020

Bogota, Colombia Date of acceptance: 05-05-2020

E-mail: mariamace9@gmail.com

2604-1731/@ 2020 Sociedad Mexicana de Oftalmología. Published by Permanyer. This is an open access article under the CC BY-NC-ND license (http://creativecommons.org/licenses/by-nc-nd/4.0/).

Available online: 01-09-2020 Rev Mex Oftalmol (Eng). 2020;94(5):199-210 www.rmo.com.mx
BY-NC-ND license 


\section{Introduction}

The World Health Organization estimated that, in 2018 , around 1.3 billion people had some form of visual impairment, and the main causes were uncorrected refractive errors and cataracts. There are approximately 36 million blind people due to cataract, trachoma, corneal scarring, glaucoma, diabetic retinopathy, age-related macular degeneration, and congenital abnormalities. It is estimated that $80 \%$ of these cases could have been avoided".

The eye is divided into anterior and posterior segments. The anterior segment includes the cornea, conjunctiva, anterior chamber, iris, ciliary body, and lens. The instillation of ophthalmic eye drops is commonly used for the treatment of anterior segment diseases due to its easy accessibility; however, topical eye drops have poor eye bioavailability due to the corneal barrier and rapid tear filtration. The posterior segment is made up of the choroid, vitreous body and retina. Ophthalmic eye drops must travel a long distance and cross several eye barriers to reach the posterior pole of the eye, leading to low bioavailability of the drug when it reaches its site of action².

Nanotechnology is a discipline that focuses on the study, design, synthesis, manipulation, and application of several materials, devices, and functional systems, and controls matter at the nanoscale (1-100 nanometers). According to the National Nanotechnology Initiative, "The essence of nanotechnology is the ability to work at the molecular level, atom by atom, to create a large structure with a fundamentally new molecular organization. The aim is to exploit these properties by gaining control of structures and devices at atomic, molecular, and supramolecular levels and to learn to efficiently manufacture and use these devices» ${ }^{3}$. It allows applications for the diagnosis, treatment, prevention and monitoring of different diseases.

The applications of nanotechnology are wide, an example is the field of molecular biology to develop bio detection methods of DNA sequencing through nanopore sequencing ${ }^{4,5}$. In clinical pharmacology, for the creation of nanomedicines ${ }^{6}$; recently, the Food and Drug Administration has approved some nanomedicines, among which are mentioned according to the type of material, polymeric nanoparticles, categorized as conjugates of polymer-drug and architecture of degradable polymers, whose functions are to promote the diffusion of the drug through anatomical barriers, increase the bioavailability and half-life of the drug, as well as favor controlled release mechanisms. It also has an application in the optimization of diagnostic images, using inorganic iron oxide nanoparticles as a reagent to improve the contrast of images ${ }^{7}$, among others.

The application of nanotechnology-based treatments in ophthalmic diseases is the hope for millions of patients suffering from eye diseases. This is the case of nanotransporters and nanosuspensions. These have the ability to release medications at specific sites, resulting in the use of a lower dose of medication, which minimizes the risk of side effects ${ }^{8}$. Brimonidine, cyclosporine, corticosteroids, sustained-release intravitreal implants, etc. are some examples. At the diagnostic and follow-up level, non-invasive measurement of intraocular pressure (IOP), used to detect high levels of IOP, and remote monitoring by means of nano-scale devices will be of great benefit for the early diagnosis of progressive optic nerve atrophy and clinical surveillance of patients with glaucomatous optic neuropathy ${ }^{9,10}$.

In this review, we have focused on therapeutic systems for eye diseases based on nanotechnology. First, we summarize a description of the ocular anatomy and the barriers involved in the administration of drugs; later, we review eye diseases and nanosystems used for their management; and finally, we present a brief perspective of nanotechnology and the existing challenges in the therapy and diagnosis of eye diseases. This review will provide information and new ideas for implementing treatments and developing frequent eye disease management systems.

\section{Eye anatomy and ocular barriers}

Table 1 presents the different anatomical ocular structures (Fig. 1), and highlights its thickness, functions and physiology, as well as their composition. These special characteristics can facilitate or impede the action of topical ocular medications. Likewise, an overview of possible targets is given, which allows understanding the implementation of nanotechnology advances in ophthalmology.

\section{Nanotechnology concepts}

Nanotechnology is a discipline focused on the study, design, synthesis, manipulation, and application of materials, devices, and functional systems, through matter control at the nanoscale level (1-100 nanometers) ${ }^{38}$.

The use of nanotechnology for the diagnosis, treatment, and control of different diseases has been rapidly implemented. This new scientific branch is called 
Table 1. Different eye structures and possible therapeutic targets

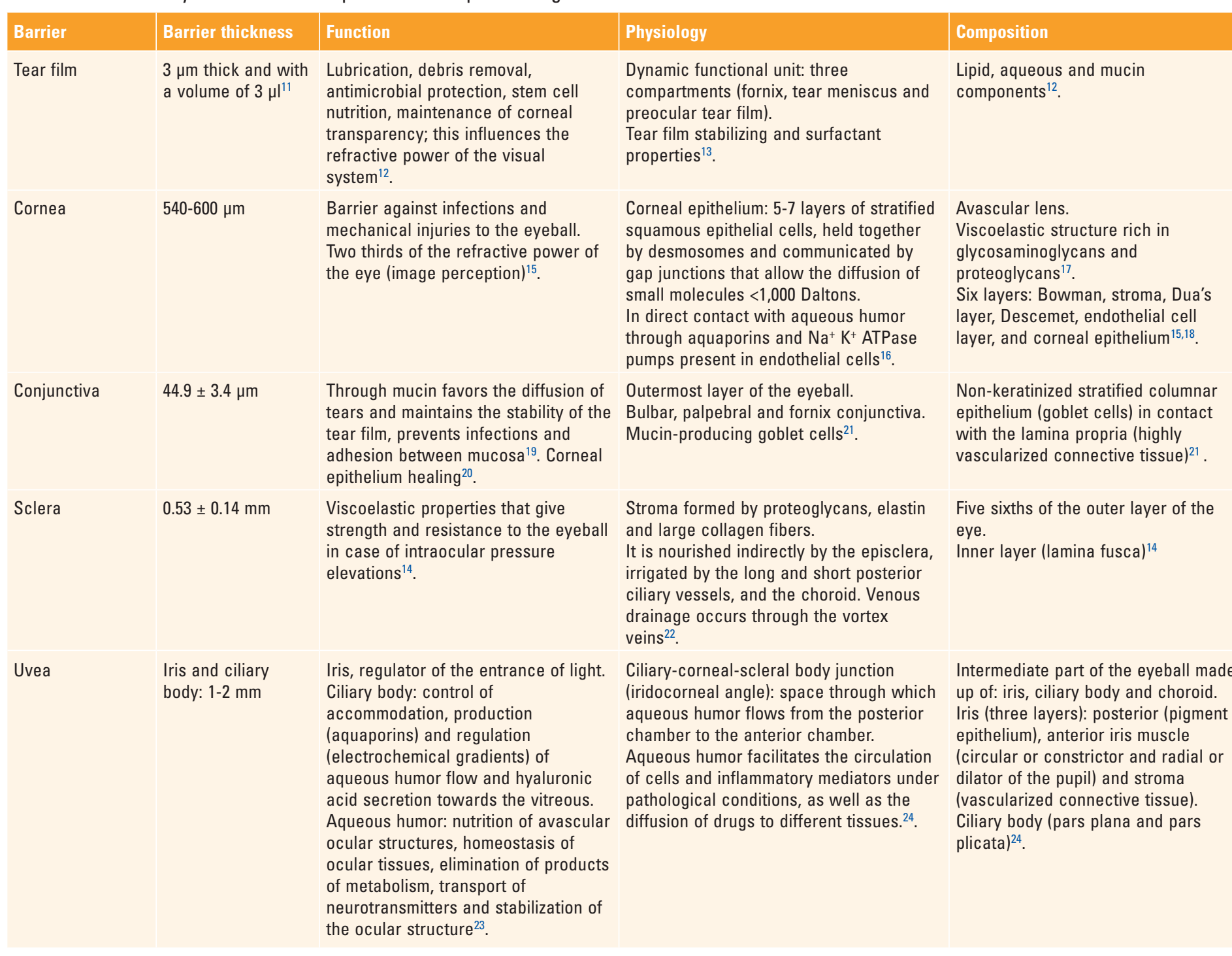

\section{Other components}

Immunoglobulins, lysozymes, lactoferrin, $\alpha$ and $\beta^{14}$.

Collagen I, III, V and VIII.

Proteoglycans (decorin, lumican, keratocan, mimecan, biglycan,

and fibromodulin) and

glycoproteins ${ }^{15,17}$.

TFF1 and TFF3 proteins are involved in corneal tissue healing process ${ }^{19}$.

Aqueous humor composed of organic and inorganic ions,

carbohydrates, glutathione, urea, amino acids, proteins

(collagenases, immunoglobulins) oxygen, carbon dioxide and water ${ }^{23}$. 
Rev Mex Oftalmol. 2020;94(5)

Table 1. Different eye structures and possible therapeutic targets (Continued)

\begin{tabular}{|c|c|c|c|c|c|c|}
\hline Barrier & Barrier thickness & Function & Physiology & Composition & & Other components \\
\hline Lens & $3.5-5 \mathrm{~mm}$ & $\begin{array}{l}\text { Dioptric power ( } 20 \% \text { of total power). } \\
\text { Focus images from the outside on the } \\
\text { retina. } \\
\text { Enzyme-mediated defense mechanism } \\
\text { against oxidizing agents (glutathione } \\
\text { reductase and catalase })^{25} \text {. }\end{array}$ & $\begin{array}{l}\text { It is nourished from the aqueous humor. } \\
\text { Metabolically active, it participates in ion } \\
\text { exchange through } \mathrm{Na}^{+}, \mathrm{K}^{+}, \mathrm{Ca}^{++} \text {and } \mathrm{Cl}^{-} \\
\text {channels, also glucose, amino acids and } \\
\text { antioxidants (glutathione })^{26} \text {. }\end{array}$ & $\begin{array}{l}\text { Clear, avascular structure. } \\
\text { Divided into capsule, lens epitheliun } \\
\text { cortex and nucleus. } \\
60 \% \text { proteins (crystalline } \alpha, \beta, \gamma \text { ). } \\
\text { Surrounded by a collagen capsule } \\
\text { (mainly type IV and XVIII), as well a } \\
\text { laminin, entactin, proteoglycans } \\
\text { (heparan sulfate), perlecan and } \\
\text { fibronectin. In the zonular region, th } \\
\text { predominant composition is due to } \\
\text { the presence of fibrillin and } \\
\text { elastin }\end{array}$ & 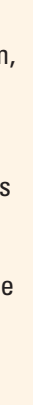 & $\begin{array}{l}\text { Membrane proteins (different } \\
\text { cell junctions of lens epithelial } \\
\text { cells): N-cadherins, calpactins, } \\
\text { type II neuronal adhesion } \\
\text { molecules, intrinsic major protein } \\
\text { (hydrophobic), and aquaporin 0, } \\
\text { enzymes (glyceraldehyde } 3 \\
\text { phosphate dehydrogenase). The } \\
\text { cytoskeleton contains actin, } \\
\alpha \text {-actinin, ankyrin, } \\
\text { thrombomodulin, myosin, } \\
\text { spectrin }^{25,26} \text {. }\end{array}$ \\
\hline Choroid & $220-350 \mu \mathrm{m}$ & $\begin{array}{l}\text { Irrigate the retina, supplying it with } \\
\text { oxygen and nutrients. } \\
\text { Light absorption, thermoregulation } \\
\text { and modulation of intraocular } \\
\text { pressure, by controlling blood flow }{ }^{27} \text {. }\end{array}$ & $\begin{array}{l}\text { Aqueous humor drainage from the } \\
\text { anterior chamber, through the uveoscleral } \\
\text { route }(35 \% \text { of its drainage })^{27} \text {. }\end{array}$ & $\begin{array}{l}\text { Blood vessels, melanocytes, } \\
\text { fibroblasts, immunocompetent cells } \\
\text { and supporting structure (collagen } \\
\text { and elastic connective tissue). } \\
\text { Four layers: Bruch's membrane, } \\
\text { choriocapillaris, two vascular layers } \\
\text { and the suprachoroid }{ }^{27} \text {. }\end{array}$ & & \\
\hline Vitreous humor & $4 \mathrm{cc}$ & $\begin{array}{l}\text { Its transparency allows the passage } \\
\text { of light to the retina and gives } \\
\text { structure to the eyeball. } \\
\text { It constitutes a barrier and challenge } \\
\text { for drugs that act at the posterior pole } \\
\text { level given their physicochemical } \\
\text { properties, as well as their ionic } \\
\text { charge }^{28} \text {. }\end{array}$ & & $\begin{array}{l}\text { Viscoelastic gel located between th } \\
\text { lens and the retina, water }(98 \%) \text {, } \\
\text { collagen fibers (II, V, IX and XI), pol } \\
\text { hyaluronic acid, electrolytes (sodiur } \\
\text { potassium, calcium, chlorine), } \\
\text { prealbumin, transferrin. } \\
\text { Corresponds to } 80 \%(4 \mathrm{cc} \text { ) of eye } \\
\text { volume }{ }^{29,30} \text {. }\end{array}$ & & More than 1,205 proteins ${ }^{30}$. \\
\hline \multirow[t]{2}{*}{$\begin{array}{l}\text { Retinal pigment } \\
\text { epithelium (RPE) }\end{array}$} & $0.4-1 \mathrm{~mm}^{31}$ & $\begin{array}{l}\text { Improves visual quality by absorbing } \\
\text { concentrated light energy in the } \\
\text { macula through the eyeball refraction } \\
\text { systems (cornea and lens). } \\
\text { Avoids photo-oxidation and oxidative } \\
\text { damage through light absorption by } \\
\text { means of the melanin contained in the } \\
\text { RPE melanosomes, carotenoids (lutein } \\
\text { and zeaxanthin), and ascorbate } \\
\text { contained in photoreceptors }{ }^{32} \text {. }\end{array}$ & $\begin{array}{l}\text { Cellular DNA repair mechanisms involved } \\
\text { as defense mechanisms against reactive } \\
\text { oxygen species } \\
\text { High blood perfusion of the } \\
\text { choriocapillaris }(1,400 \mathrm{cc} / \mathrm{min} / 100 \mathrm{gr} \text { of } \\
\text { tissue })^{34} \text {. } \\
\text { Transports ions and water from the } \\
\text { subretinal space to the choriocapillaris } \\
\text { through } \mathrm{Na}^{+} \mathrm{K}^{+} \mathrm{ATPase} \text { pumps and } \mathrm{K}^{+} / \mathrm{Cl}- \\
\text { transporters, maintaining to some extent } \\
\text { intraocular pressure }\end{array}$ & & 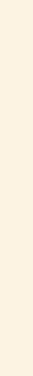 & $\begin{array}{l}\text { Antioxidant agents: superoxide } \\
\text { dismutase and catalase. } \\
\text { The maintenance of intracellular } \\
\mathrm{pH} \text { is mediated by the chloride- } \\
\text { bicarbonate exchangers located } \\
\text { in the RPE basolateral } \\
\text { membrane }^{33} \text {. }\end{array}$ \\
\hline & & & & & & (Continues) \\
\hline
\end{tabular}


Table 1. Different eye structures and possible therapeutic targets (Continued)

\begin{tabular}{|c|c|c|c|}
\hline Barrier & Barrier thickness & Function & Physiology \\
\hline $\begin{array}{l}\text { Sensorineural } \\
\text { retina }\end{array}$ & & $\begin{array}{l}\text { Phototransduction of external } \\
\text { images }^{36} \text {. }\end{array}$ & $\begin{array}{l}\text { Irrigated by the central retinal artery and } \\
\text { receives metabolic nutrients through the } \\
\text { choroid }{ }^{31} \text {. Self-regulation of retinal } \\
\text { pressure is primarily mediated by } \\
\text { increased vascular resistance of the } \\
\text { retinal vessels }{ }^{37} \text {. }\end{array}$ \\
\hline
\end{tabular}

Table 2. Frequent eye disorders and therapeutic applications

\begin{tabular}{|c|c|c|c|c|}
\hline Disorder & Medication/device & Therapeutic target & Associated nanoparticle & Niochanism of action \\
\hline Keratitis & $\begin{array}{l}\text { Ofloxacin, eye drops } \\
\text { Acyclovir }\end{array}$ & $\begin{array}{l}\text { Fluoroquinolone. Inhibition of topoisomerase II } \\
\text { and IV. } \\
\text { Herpes virus DNA polymerase inhibitor }\end{array}$ & $\begin{array}{l}\text { Polyethylene oxide and Eudragit }{ }^{\circledR} \text { in } \\
\text { the form of microspheres } \\
\text { Acyclovir prodrugs encapsulated in } \\
\text { polylactic-co-glycolic acid } \\
\text { microspheres }\end{array}$ & 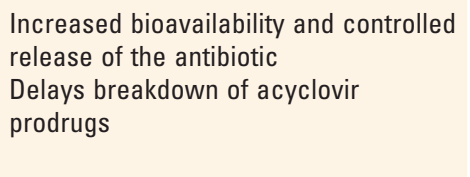 \\
\hline Conjunctivitis & Tobramycin, eye drops ${ }^{96}$ & $\begin{array}{l}\text { Inhibition of the synthesis and binding of } \\
\text { polypeptides in the ribosome }\end{array}$ & Solid lipids NP & $\begin{array}{l}\text { Increase the bioavailability on the } \\
\text { corneal surface and favor its retention } \\
\text { in the conjunctival sac }\end{array}$ \\
\hline $\begin{array}{l}\text { Keratoconjunctivitis } \\
\text { sicca }\end{array}$ & Cyclosporin A, eye drops ${ }^{97}$ & $\begin{array}{l}\text { Immunomodulator that prevents T-lymphocyte } \\
\text { activation }\end{array}$ & Chitosan & Sustained release vehicle \\
\hline Uveitis & $\begin{array}{l}\text { Prednisolone nanosuspensions } s^{52} \\
\text { Subconjunctival prednisolone injection }{ }^{52} \\
\text { Intravitreal infliximab }\end{array}$ & $\begin{array}{l}\text { Inhibitor of the synthesis of prostaglandins and } \\
\text { leukotrienes } \\
\text { Monoclonal antibody that inhibits TNF- } \alpha \\
\text { activity }\end{array}$ & $\begin{array}{l}\text { Submicron colloidal vehicle for } \\
\text { hydrophobic drugs in a medium } \\
\text { stabilized by surfactants } \\
\text { Pegylated liposomal formulation } \\
\text { Liposomal transporter }\end{array}$ & 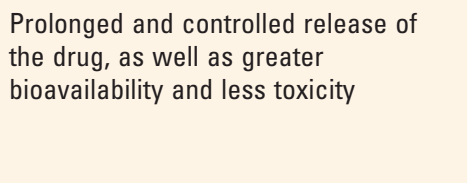 \\
\hline \multirow[t]{2}{*}{ Cataract } & IOL with metabolic activity ${ }^{98}$ & $\begin{array}{l}\text { Inhibit the activity of ROS and regulate the } \\
\text { levels of } \mathrm{H}_{2} \mathrm{O}_{2} \text { and lipid hydroperoxides in the } \\
\text { surrounding medium }\end{array}$ & $\begin{array}{l}\text { Platinum nanocoating deposited by } \\
\text { a magnetron sprayer }\end{array}$ & Catalytic inorganic antioxidant \\
\hline & & & & (Continues) \\
\hline
\end{tabular}


Rev Mex Oftalmol. 2020;94(5)

Table 2. Frequent eye disorders and therapeutic applications (Continued)

\begin{tabular}{|c|c|c|c|c|}
\hline Disorder & Medication/device & Therapeutic target & Associated nanoparticle & NF mechanism of action \\
\hline Glaucoma & $\begin{array}{l}\text { Nano transporters of: pilocarpine, timolol, } \\
\text { carbonic anhydrase inhibitors, acetazolamide, } \\
\text { dorzolamide, brinzolamide, brimonidine }{ }^{99} \\
\text { Timolol-containing silicone and hydrogel } \\
\text { contact lenses }^{74} \\
\text { Timolol contact lenses } \\
\text { Wireless sensors }^{95}\end{array}$ & $\begin{array}{l}\text { Drugs used in traditional glaucoma treatment } \\
\text { Non-selective } \beta \text {-blocker that decreases the } \\
\text { production of aqueous humor } \\
\text { Continuous IOP monitoring }\end{array}$ & $\begin{array}{l}\text { Dendrimers, liposomes, nano } \\
\text { capsules, nanospheres, hydrogels } \\
\text { PGT (Propoxylated glyceryl } \\
\text { triacylate) } \\
\text { Gold NP }\end{array}$ & 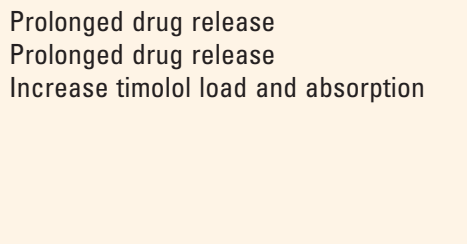 \\
\hline Wet AMD & $\begin{array}{l}\text { Hyaluronic acid: bevacizumab implant }{ }^{100} \\
\text { Biodegradable Nano porous Film Device: } \\
\text { ranibizumab }^{92}\end{array}$ & $\begin{array}{l}\text { Humanized monoclonal antibody against } \\
\text { vascular endothelial growth factor }\end{array}$ & $\begin{array}{l}\text { Chitosan } \\
\text { NA }\end{array}$ & $\begin{array}{l}\text { Sustained release vehicle } \\
\text { Rêlease of the drug through nanopores } \\
\text { O } \\
\text { o }\end{array}$ \\
\hline Diabetic retinopathy & $\begin{array}{l}\text { Stimulus-responsive reservoir device: } \\
\text { nintedanib }{ }^{101}\end{array}$ & $\begin{array}{l}\text { Angiokinase inhibitor, blocking VEGF receptors, } \\
\text { platelet-derived growth factor receptors, and } \\
\text { fibroblast growth factor receptors }\end{array}$ & $\begin{array}{l}\text { Poly(lactic-co-glycolic acid) } \\
\text { microspheres and onitrobenzyl } \\
\text { monomers }\end{array}$ & $\begin{array}{l}\text { Drang release through ultraviolet light } \\
\text { stimulation } \\
\text { c. } \\
\frac{c}{\mathrm{c}}\end{array}$ \\
\hline Retinitis pigmentosa & Intravitreal fluocinolone acetonide ${ }^{59}$ & Attenuation of microglial activity & Polyamidoamine dendrimers & Sustained drug release \\
\hline Retinoblastoma & $\begin{array}{l}\text { Subconjunctival carboplatin } \\
\text { Verteporfin photodynamic therapy }\end{array}$ & $\begin{array}{l}\text { Alkylating agent, inhibits DNA replication, RNA } \\
\text { transcription, and protein synthesis } \\
\text { Selective damage to neovessel endothelial } \\
\text { cells, apoptosis and autophagy inducer }\end{array}$ & $\begin{array}{l}\text { Dendrimeric polyamidoamine NP } \\
\text { Activation of liposomal verteporfin } \\
\text { by a non-thermal laser }\end{array}$ & $\begin{array}{l}\text { Prolonged and controlled drug release } \\
\text { ROS production and cell death on } \\
\text { tumor cells } \\
\end{array}$ \\
\hline $\begin{array}{l}\text { Retinopathy of } \\
\text { prematurity }\end{array}$ & Intravitreal gold NP103 & NA & Gold NP & $\begin{array}{l}\text { Suppression of the VEGFR-2 signaling } \\
\text { pathway by autophosphorylation and } \\
\text { blogking activation of ERK1 and } 2\end{array}$ \\
\hline Optic neuromyelitis & Biosensor ${ }^{104}$ & NA & Carbon nanotubes & AQP4 antibody detection \\
\hline Endophthalmitis & Daptomycin, eye drops ${ }^{105}$ & $\begin{array}{l}\text { Natural lipopeptide antibiotic against gram- } \\
\text { positives, including MRSA }\end{array}$ & Chitosan & $\begin{array}{l}\text { Prômotes penetration of the antibiotic } \\
\text { by opening the intercellular junctions } \\
\text { of ghe cornea }\end{array}$ \\
\hline $\begin{array}{l}\text { AMD: age-related macular } \\
\text { Staphylococcus aureus; } \mathrm{V}\end{array}$ & $\begin{array}{l}\text { degeneration; ERK: kinase regulated by extracellular sign } \\
\text { GFR-2: vascular endothelial growth factor receptor } 2 \text {. }\end{array}$ & OL: intraocular lens; NA: not applicable; NP: nanoparticle & IOP: intraocular pressure, ROS: reactive ox & 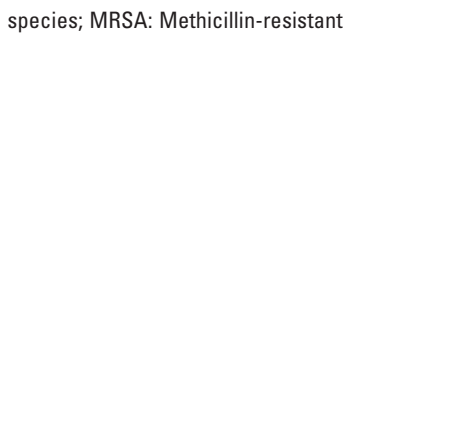 \\
\hline
\end{tabular}




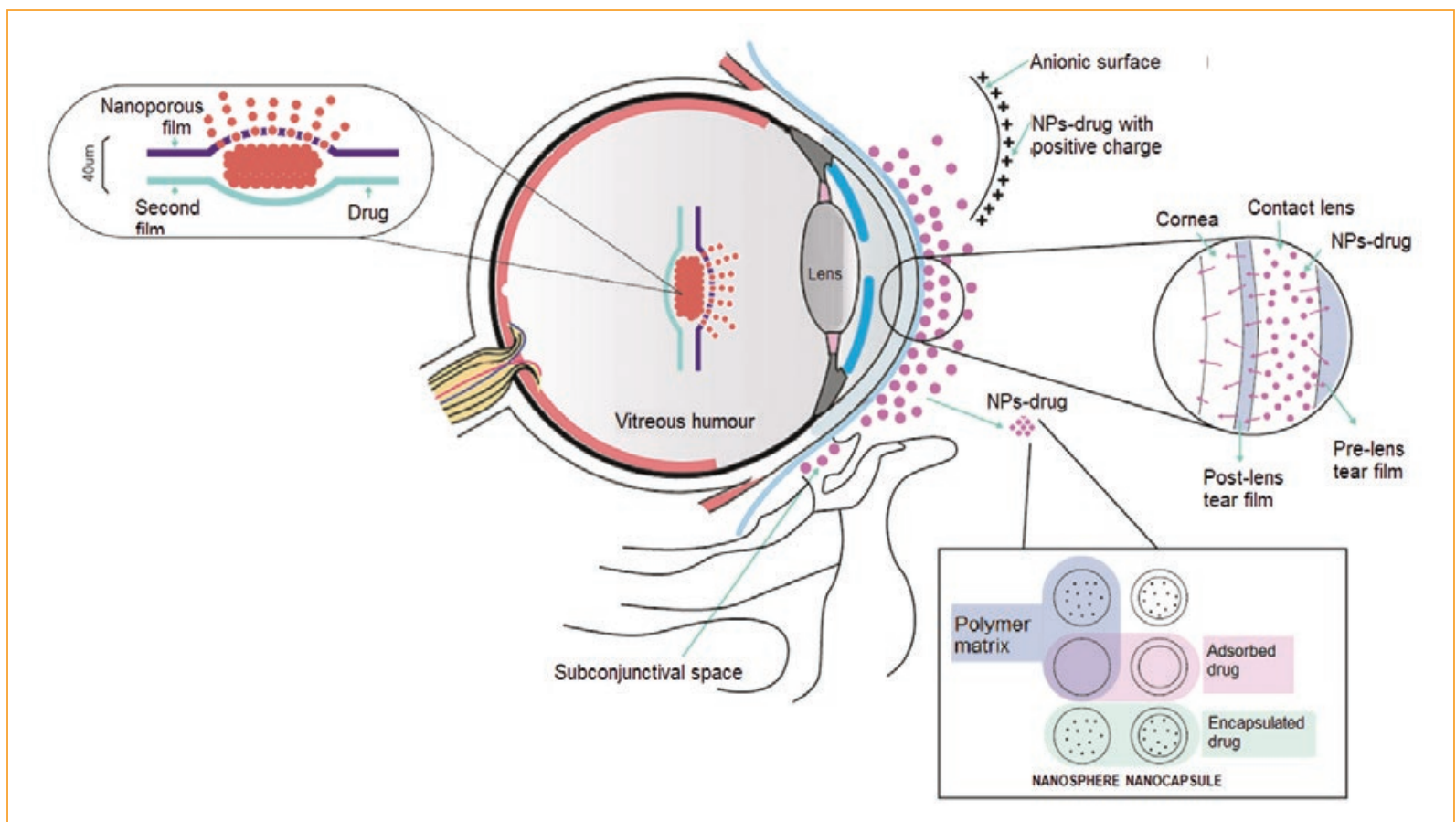

Figure 1. Administration of ophthalmic drugs by nanotechnology through the different ocular anatomical structures. NP: nanoparticles.

nanomedicine. The evolution of knowledge about nanotechnology in medical-surgical areas has allowed the progress of applications in ophthalmology. Thus, novel ocular nanosystems have been designed in different ways and with specific characteristics to optimize drug bioavailability, by improving contact time and decreasing the clearance process ${ }^{39}$.

There are many nanosystems. Among others, nanoparticle-loaded contact lenses to administer acetazolamide in the treatment of glaucoma ${ }^{40}$, biodegradable subconjunctival implants to administer cyclosporin A for the treatment of dry eye syndrome ${ }^{41,42}$, development of hydrogel-based nano colloidal systems for the ocular release of diclofenac ${ }^{43,44}$, polymeric nano micellar systems for inflammatory diseases ${ }^{45,46}$, and nanostructured lipid transporters for the controlled supply of ocular drugs for infections ${ }^{47,48}$.

\section{Liposomes}

Liposomes are lipid vesicles, with one or more phospholipid bilayers, that enclose an aqueous nucleus. Depending on their size and the number of phospholipid bilayers, liposomes can be classified into small unilamellar vesicles (10 and $100 \mathrm{~nm}$ ), large unilamellar vesicles (100 and $300 \mathrm{~nm}$ ), and multilamellar vesicles, which contain more than a single phospholipid bilay$\mathrm{er}^{49}$. Liposomes are ideal because they encapsulate both hydrophilic and hydrophobic drugs and demonstrate very good compatibility with ocular tissues ${ }^{50,51}$. Examples of such nanoparticles are prednisolone nanosuspensions and intravitreal infliximab with liposomal nanocarrier ${ }^{52.53}$.

\section{Polymeric nanoparticles}

Polymeric micelles are core/shell structured nanoparticles formed by the self-assembly of amphiphilic copolymers. The core/shell structure allows the encapsulation of hydrophobic drugs in their hydrophobic core. Because the nucleus is protected by the hydrophilic crown, drug bioavailability is significantly prolonged when it is administered topically to ocular tissues ${ }^{54,55}$. An experimental study developed by Mittal, et al. with topical timolol maleate in rabbits, showed biocompatibility with the cornea and decreased IOP for longer times ${ }^{56}$.

\section{Nanosuspensions}

They are colloidal dispersions in which hydrophobic drugs are uniformly dispersed in an aqueous medium with the help of surfactants ${ }^{9}$. Prednisone, dexamethasone, 
hydrocortisone, and other corticosteroids, for example, have been administered through nanosuspensions for the treatment of anterior segment inflammation, without the expected side effects of high-dose applications, such as in cataract and glaucomatous optic neuropathy.

\section{Dendrimers}

Dendrimers are monodispersed macromolecules with several reactive end groups that surround a small molecule and form an internal cavity. Its branched tree-like architecture features a variety of repetitive end groups. Especially low-generation dendrimers can encapsulate hydrophobic drug molecules in their internal cavities. Due to this unique structure, dendrimers allow the solubilization of drugs that are poorly soluble in water. Furthermore, dendrimers can be considered as a true imitation of globular proteins. They are known as "artificial proteins", based on their systematic, electrophoretic, dimensional scale properties, and other biomimetic properties ${ }^{57,58}$.

Drugs developed with this technology include intravitreal fluocinolone acetonide for the treatment of retinitis pigmentosa, and subconjunctival carboplatin for retinoblastoma management ${ }^{59,60}$.

\section{Nano micelles}

They are drug delivery systems composed of a hydrophobic core and a hydrophilic shell, which allow the dissolution of hydrophobic drugs, with the generation of a clear aqueous formulation for drug administration in the anterior segment of the eye. One of the drugs administered with this type of nanotechnology is cyclosporine. A phase III clinical trial demonstrated its effectiveness, safety, and rapid action in the treatment of keratoconjunctivitis sicca ${ }^{61}$.

\section{Niosomes}

Niosomes are double-layered nonionic surfactant vesicles, which can trap hydrophilic and lipophilic drugs. Niosomes are chemically stable and their nonionic nature facilitates their low toxic potential ${ }^{62}$. Thanks to their hydrophilic surface, niosomes easily interact and cross the tear film barrier, and as a result they can reach corneal/conjunctival tissue ${ }^{63}$. Niosomes have been evaluated as anticholinergics, anti-glaucomatous, and antibiotics $62,64,65$. The most determining characteristics for use as vehicles for the administration of ocular drugs are: the size of the vesicle, large enough to resist drainage by reflex tearing and blinking; irregular shapes that allow correct placement into the cul-de-sac and permanence on the ocular surface; be heat-sensitive to release the content of the drug in a controlled manner, but at the same time, before being removed through blinking and nasolacrimal drainage ${ }^{66,67}$.

\section{Cubosomes}

The structure of the cubosome consists of a highly twisted continuous lipid bilayer, with two congruent non-crossing water channels. Compared to the simple bilayer structure of liposomes, cubosomes have an increased surface area and a great ability to encapsulate various molecules of hydrophilic, hydrophobic, and amphiphilic substances. Cubosomes have a higher physical-chemical stability than liposomes, due to the strong electrical repulsion and a large proportion of lipid bilayer ${ }^{68-70}$. The use of dexamethasone eye drops, associated with this type of nanoparticle, evidences a greater availability of the drug in the aqueous humor ${ }^{71}$.

\section{Hydrogels}

They are a network of multifunctional monomers and relays that react to form a flexible structure loaded with water. Hydrogel networks have been extensively studied as a controlled and sustained drug delivery systems, since the porosity of their matrix can be adapted by changing the density of the crosslinking. This ability to change depending on the surrounding environment has important implications for in situ formed hydrogels, those that cross-link when the temperature increases from room temperature to body temperature, as well as the controlled release of drugs as a result of $\mathrm{pH}$ or photostimulation $^{72.73}$. Controlled-release timolol-containing silicone and hydrogel contact lenses are a promising newly developed technology ${ }^{74}$.

\section{Polymeric nanofibers}

Nanofibers are solid fibers of materials that have diameters below the micron range, with a porous structure and a very high surface area.

Nanofibers are nonwoven fibrous structures, similar to the extracellular matrix, consisting of an aqueous compound of highly organized polymeric fibrils and proteoglycans to support tissue formation. For this reason, one of its main applications is in tissue engineering. Keratoprosthesis are devices for which studies have been conducted with the aim to safeguard the 
biocompatibility, physiology and, therefore, the most important property of the cornea, its transparency ${ }^{75,76}$.

Additionally, due to their very small diameter and exceptionally high surface area, nanofibers allow loading a significantly higher drug content into a very small portion of a patch ${ }^{77.78}$.

\section{Nano formulations for the treatment of eye diseases}

Much of the ophthalmic products on the market are topical formulations for the administration of drugs to the anterior segment. The biggest disadvantage is that only $5 \%$ of the instilled dose reaches the anterior chamber, and the one that penetrates the posterior segment is smaller, due to the multiple and complex anatomical barriers of the eyeball. The administration of nano-sized ophthalmic drugs (Fig. 1) represents advantages due to greater solubility, greater dissolution surface available, greater dissolution speed, greater bio adhesion and corneal penetration. The recommendation is that particles measure less than $10 \mu \mathrm{m}$ to minimize irritation of the ocular structures, decrease tearing and drainage of the instilled dose, and therefore increase the efficacy of ocular treatments.

\section{Nanosuspensions}

Nanosuspensions are submicron colloidal dispersions of pure drug particles in an external liquid phase. An important feature of nanosuspensions is the increased saturation solubility and, consequently, an increased dissolution rate of the compound. In this system, drugs are loaded by matrix binding or dissolved, encapsulated or trapped within the framework, generating a versatile drug delivery system that includes microemulsions, liposomes, niosomes, dendrimers and cyclodextrins ${ }^{79.80}$.

The advantages of nanoparticle use include the improved topical passage of large and poorly water-soluble molecules, such as glucocorticoids or cyclosporine, to treat immunological diseases that affect vision ${ }^{81}$. Other large and unstable molecules, such as nucleic acids, administered by nanoparticles, offer promising results for gene transfer therapy in the treatment of retinopathies ${ }^{82,83}$. Nanoparticle-mediated drug administration increases the contact time of the administered medication with its target tissue, as is the case of brimonidine, one of the traditional treatments for glaucoma, or corticosteroids used to treat autoimmune uveitis $^{78,84}$. Some nanoformulations have allowed the non-steroidal anti-inflammatory drug, indomethacin, to reach the posterior internal structures of the eye using the transmucosal route ${ }^{85}$. New applications include the use of gold nanoparticles that allow targeted delivery to reach specific types of cancer, such as choroidal melanoma, without affecting healthy cells ${ }^{86}$.

\section{Contact lenses}

Contact lenses are rigid or soft polymeric devices designed to fit directly on the cornea to correct refractive abnormalities. In 1965, Wichterle, et al. patented the idea of using hydrogel contact lenses as drug delivery devices. The patent mentions the inclusion of drugs in lens hydration to offer greater availability of the drug during use ${ }^{87}$.

The inclusion of drug-loaded nanoparticles within the contact lens polymer matrix is an effective strategy for prolonged drug delivery. Drug incorporation is accomplished with methods such as printing, simple soaking, and colloidal nanoparticles ${ }^{88-90}$. Nanoparticle diameter must be extremely small for use in contact lenses to prevent particles from obstructing the user's vision. Therefore, it is necessary to delay the release of the drug through other means. This can be accomplished by linking the drug to the particle through a cleavable chemical bond or by designing a particle that allows a higher affinity of the drug for the particle than for the material of the surrounding lens ${ }^{89}$. This approach allows sustained release, which can be adjusted to the patient's needs, from a few hours to several weeks, enabling the treatment of pathologies of the anterior segment.

Different nanoparticles have been patented, especially liposomes and microemulsions that contain the drug and are then loaded into contact lenses. Liposomes have been used in several drug delivery applications due to their high biocompatibility; lenses remain clear and release the drug for a few days, with an initial release that is attributed to the non-encapsulated drug present in the lens. Contact lenses loaded with microemulsions will release the drug for 4 to 8 days, with an initial peak attributed to the non-encapsulated drug ${ }^{89}$.

In 2013, Jung, et al. dispersed the timolol nanoparticles of PGT (propoxylated glyceryl triacrylate) in silicone contact lenses to administer the drug for 30 days. Preliminary studies in Beagle dogs showed promising results for glaucoma. The incorporation of nanoparticles in silicone hydrogels caused a reduction in ion and oxygen permeability and an increase in modulus; the impact on each of these properties was proportional to particle charge ${ }^{74}$. In 2018, Maulvi, et al. incorporated 
gold nanoparticles into contact lenses and improved the absorption of timolol from the drug's solvent solution along with satisfactory dynamic and kinetic results in vivo, without altering the properties of the lens ${ }^{91}$. The evaluated devices exhibited excellent mechanical properties, and the researchers propose that the material is suitable for the supply of drugs from reusable daily contact lenses.

\section{Intraocular implants}

Eye implants are new treatments that seek the controlled release of drugs, through higher dosages and drug loads. In addition, there are systemic side effects and greater proximity to the target site, the posterior segment of the eye. Biodegradable or non-biodegradable polymers can be used in implantable eye systems. Biodegradable implants do not need to be removed after insertion into the eye, but non-biodegradable implants require an additional intervention for removal or filling, carrying additional costs, and intra or postoperative surgical risks. The most recent developments in biodegradable implantable systems are the Envisia Therapeutics ENV705 ${ }^{\mathrm{TM}}$ Implant and the Zordera ${ }^{92}$ nanoporous film device.

The Zordera nanoporous film device consists of a drug in the pellet sealed between two thin waterproof biodegradable membrane layers. One side has nanopores of the same diameter as the active drug substance, allowing only one drug molecule to leave the reservoir of each pore at a time. The device is injected into the vitreous; it is very thin, with a diameter of only $40 \mu \mathrm{m}$ and a sustained drug release of almost zero-order. The polymer layers degrade at a later time when most of the drug has been released, eliminating the need to remove the device. This implant offers control over the release rate by adjusting pore size, and has demonstrated to administer ranibizumab for four months on a continuous basis. Therefore, it can become the best biodegradable implant to treat chronic retinal conditions ${ }^{93}$. A similar case occurs with sirolimus release in the posterior segment using this same device ${ }^{94}$.

\section{Clinical applications}

After understanding the anatomy, histology and, physiology of the different eye barriers, as well as the main nanoparticles that have been developed in the field of research, Table 2 lists the most frequent eye disorders and those with the greatest negative impact on visual acuity for which nanotechnology has been used as a treatment targeted for different ocular tissues (Fig. 1).

\section{Perspectives}

The range of applications of nanotechnology and nanomedicine in the field of ophthalmology is wide. The use of these devices and nanoformulations favors drug bioavailability, allows diffusion across anatomical barriers, and could decrease the adverse effects attributed to the use of conventional topical eye drugs, and very possibly decrease, to some extent, invasive interventions in the posterior pole, as well as complications secondary to the use of certain medications that require surgical procedures for their implantation. Ultimately, the benefits of drugs are optimized and their negative impacts are reduced, and a large window opens within the spectrum of so-called personalized medicine, which will most likely require new studies with particular designs for populations with individual characteristics, as well as the continuous study in different animal and laboratory models.

\section{Conflicts of interest}

The authors declare no conflicts of interest.

\section{Ethical disclosures}

Protection of human and animal subjects. The authors declare that no experiments were performed on humans or animals for this study.

Confidentiality of data. The authors declare that no patient data appear in this article.

Right to privacy and informed consent. The authors declare that no patient data appear in this article.

\section{References}

1. Salud OOMdl. Ceguera y discapacidad visual. 2019. Disponible en: https://www.who.int/es/news-room/fact-sheets/detail/blindness-and-visual-impairment

2. Meng T, Kulkarni V, Simmers R, Brar V, Xu Q. Therapeutic implications of nanomedicine for ocular drug delivery. Drug discovery today. England: 2019 Elsevier Ltd; 2019.

3. NSTC. NATIONAL NANOTECHNOLOGY INITIATIVE - LEADING TO THE NEXT INDUSTRIAL REVOLUTION. Microscale Thermophysical Engineering. 2000;4(3):205-12.

4. Guchet $X$. What's in a word? The person of personalized (nano)medicine. Nanomedicine (Lond). 2015;10(20):3167-79.

5. Feng Y, Zhang Y, Ying C, Wang D, Du C. Corrigendum to 'Nanopore-based Fourth-generation DNA Sequencing Technology' [GPB 144 (2015) - GPB 13/1 (4-16)]. Genomics Proteomics Boinformatics. 2015;13(6):383.

6. Peck RW. Precision Medicine Is Not Just Genomics: The Right Dose for Every Patient. Ann Rev Pharmacol Toxicol. 2018;58:105-22.

7. Ventola CL. Progress in Nanomedicine: Approved and Investigational Nanodrugs. P \& T: a peer-reviewed journal for formulary management. 2017;42(12):742-55. 
8. Xu Q, Kambhampati SP, Kannan RM. Nanotechnology approaches fo ocular drug delivery. Middle East Afr J Ophthalmol. India2013. p. 26-37.

9. Kamaleddin MA. Nano-ophthalmology: Applications and considerations Nanomedicine. United States: 2017 Elsevier Inc; 2017. p. 1459-72.

10. Zarbin MA, Arlow T, Ritch R, Wang YY, Lai SK, Ensign LM, et al. Regenerative nanomedicine for vision restoration The microstructure and bulk rheology of human cervicovaginal mucus are remarkably resistant to changes in $\mathrm{pH}$. Mayo Clin Proc. England United States: 2013 Mayo Foundation for Medical Education and Research. Published by Elsevier Inc; 2013. p. 1480-90.

11. Dartt DA, Willcox MD. Complexity of the tear film: importance in homeostasis and dysfunction during disease. Exp Eye Res. 2013;117:1-3.

12. Gulati S, Jain S. Ocular Pharmacology of Tear Film, Dry Eye, and Allergic Conjunctivitis. Handbook Exp Pharmacol. 2017;242:97-118.

13. Willcox MDP, Argueso P, Georgiev GA, Holopainen JM, Laurie GW, Millar TJ, et al. TFOS DEWS II Tear Film Report. Ocul Surf. 2017; 15(3):366-403.

14. Sridhar MS. Anatomy of cornea and ocular surface. Indian J Ophthalmol. 2018;66(2):190-4

15. Ma J, Wang $Y$, Wei $P$, Jhanji V. Biomechanics and structure of the cornea: implications and association with corneal disorders. Surv Ophthalmol. 2018;63(6):851-61.

16. Williams K, Watsky M. Gap junctional communication in the human corneal endothelium and epithelium. Curr Eye Res. 2002;25(1):29-36.

17. Kling S, Hafezi F. Corneal biomechanics - a review. Ophthalmic Physio Opt. 2017;37(3):240-52

18. Zavala J, Lopez Jaime GR, Rodriguez Barrientos CA, Valdez-Garcia J. Corneal endothelium: developmental strategies for regeneration. Eye (London, England). 2013;27(5):579-88.

19. Takahashi $Y$, Watanabe A, Matsuda H, Nakamura Y, Nakano T, Asamoto $\mathrm{K}$, et al. Anatomy of secretory glands in the eyelid and conjunctiva: a photographic review. Ophthal Plastic Rec Surg. 2013;29(3):215-9.

20. Gipson IK. Goblet cells of the conjunctiva: A review of recent findings. Progress Retinal Eye Res. 2016;54:49-63.

21. Galicia-Carreon J, Santacruz C, Hong E, Jimenez-Martinez MC. The ocular surface: from physiology to the ocular allergic diseases. Revista Alergia Mexico (Tecamachalco, Puebla, Mexico : 1993). 2013;60(4):172-83.

22. Watson PG, Young RD. Scleral structure, organisation and disease. A review. Exp Eye Res. 2004;78(3):609-23.

23. Davis-Silberman N, Ashery-Padan R. Iris development in vertebrates: genetic and molecular considerations. Brain Res. 2008;1192:17-28.

24. Civan MM, Macknight AD. The ins and outs of aqueous humour secretion. Exp Eye Res. 2004;78(3):625-31.

25. Aliancy JF, Mamalis N. Crystalline Lens and Cataract. In: Kolb H, Fernandez E, Nelson R, editors. Webvision: The Organization of the Retina and Visual System. Salt Lake City UT: Webvision; 2017.

26. Assia El, Apple DJ. Side-view analysis of the lens. I. The crystalline lens and the evacuated bag. Arch Ophthalmol. (Chicago, III : 1960). 1992;110(1):89-93.

27. Nickla DL, Wallman J. The multifunctional choroid. Prog Retin Eye Res. 2010;29(2):144-68.

28. Mains J, Wilson CG. The vitreous humor as a barrier to nanoparticle distribution. J Ocul Pharmacol Ther. 2013:29(2):143-50.

29. Mulla A, Massey KL, Kalra J. Vitreous humor biochemical constituents: evaluation of between-eye differences. Am J Forensic Med Pathol. 2005;26(2):146-9.

30. Murthy KR, Goel R, Subbannayya Y, Jacob HK, Murthy PR, Manda SS et al. Proteomic analysis of human vitreous humor. Clin Proteomics. 2014;11(1):29.

31. Willoughby CE, Ponzin D, Ferrari S, Lobo A, Landau K, Omidi Y. Anatomy and physiology of the human eye: effects of mucopolysaccharidoses disease on structure and function - a review. Clin Exp Ophthal. 2010;38(s1):2-11.

32. Simo R, Villarroel M, Corraliza L, Hernandez C, Garcia-Ramirez M. The retinal pigment epithelium: something more than a constituent of the blood-retinal barrier--implications for the pathogenesis of diabetic retinopathy. J Biomed Biotechnol. 2010;2010:190724.

33. Strauss $O$. The retinal pigment epithelium in visual function. Physiologica Rev. 2005;85(3):845-81.

34. Sparrow JR, Hicks D, Hamel CP. The retinal pigment epithelium in health and disease. Curr Mol Med. 2010;10(9):802-23.

35. Boulton M, Dayhaw-Barker P. The role of the retinal pigment epithelium: topographical variation and ageing changes. Eye (London, England). 2001:15(Pt 3):384-9.

36. Gupta MP, Herzlich AA, Sauer T, Chan CC. Retinal Anatomy and Pathology. Develop Ophthalmol. 2016;55:7-17.

37. Harris A, Ciulla TA, Chung HS, Martin B. Regulation of retinal and optic nerve blood flow. Arch Ophthalmol (Chicago, III : 1960). 1998;116(11):1491-5.

38. Gómez M. Nanomateriales, Nanopartículas y Síntesis verde. Repert Med Cir. 2018;27(2):75-80

39. Weng Y, Liu J, Jin S, Guo W, Liang X, Hu Z. Nanotechnology-based strategies for treatment of ocular disease. Acta Pharm Sin B. 2017; $7(3): 281-91$.
40. Prakash M, Dhesingh RS. Nanoparticle Modified Drug Loaded Biodegradable Polymeric Contact Lenses for Sustainable Ocular Drug Delivery. Current drug delivery. United Arab Emirates: Bentham Science Publishers; For any queries, please email at epub@benthamscience.org.; 2017. p. 555-65

41. Yavuz B, Bozdag Pehlivan S, Kaffashi A, Calamak S, Ulubayram K, Palaska $E$, et al. In vivo tissue distribution and efficacy studies for cyclosporin A loaded nano-decorated subconjunctival implants Comparative study of human embryonic stem cells (hESC) and human induced pluripotent stem cells (hiPSC) as a treatment for retinal dystrophies. Drug delivery. England United States 2016. p. 3279-84.

42. Pehlivan SB, Yavuz B, Calamak S, Ulubayram K, Kaffashi A, Vural I, et al. Preparation and in vitro/in vivo evaluation of cyclosporin A-loaded nanodecorated ocular implants for subconjunctival application. J Pharm Sci. 2015;104(5):1709-20.

43. Li X, Zhang Z, Chen $\mathrm{H}$. Development and evaluation of fast forming nano-composite hydrogel for ocular delivery of diclofenac. Int J Pharm. 2013:448(1):96-100.

44. Li X, Zhang Z, Li J, Sun S, Weng Y, Chen H. Diclofenac/biodegradable polymer micelles for ocular applications. Nanoscale. 2012;4(15):4667-73.

45. Salama AH, Shamma RN Tri/tetra-block co-polymeric nanocarriers as a potential ocular delivery system of lornoxicam: in-vitro characterization, and in-vivo estimation of corneal permeation. International journal of pharmaceutics. 2015;492(1-2):28-39.

46. Silva-Abreu M, Calpena AC, Espina M, Silva AM, Gimeno A, Egea MA, et al. Optimization, Biopharmaceutical Profile and Therapeutic Efficacy of Pioglitazone-loaded PLGA-PEG Nanospheres as a Novel Strategy for Ocular Inflammatory Disorders. Pharm Res. 2018;35(1):11.

47. Ustundag-Okur N, Gokce EH, Bozbiyik DI, Egrilmez S, Ertan G, Ozer O. Novel nanostructured lipid carrier-based inserts for controlled ocular drug delivery: evaluation of corneal bioavailability and treatment efficacy in bacterial keratitis. Exp Op Drug Deliv. 2015;12(11):1791-807.

48. Ustundag-Okur N, Gokce EH, Bozbiyik DI, Egrilmez S, Ozer O, Ertan G. Preparation and in vitro-in vivo evaluation of ofloxacin loaded ophthalmic nano structured lipid carriers modified with chitosan oligosaccharide lactate for the treatment of bacterial keratitis. Eur J Pharm Sci. 2014:63:204-15.

49. Kaiser JM, Imai H, Haakenson JK, Brucklacher RM, Fox TE, Shanmugavelandy SS, et al. Nanoliposomal minocycline for ocular drug delivery. Nanomedicine. 2013:9(1):130-40.

50. Campos EJ, Campos A, Martins J, Ambrosio AF, Bisht R, Mandal A, et al. Opening eyes to nanomedicine: Where we are, challenges and expectations on nanotherapy for diabetic retinopathy Nanocarrier mediated retinal drug delivery: overcoming ocular barriers to treat posterior eye diseases Intraocular application of gold nanodisks optically tuned for optical coherence tomography: inhibitory effect on retinal neovascularization without unbearable toxicity Surface plasmon-enhanced fluorescence on Au nanohole array for prostate-specific antigen detection. Nanomedicine. United States New Zealand: 2017 Elsevier Inc 2017 Wiley Periodicals, Inc.; 2017. p. 2101-13.

51. Honda M, Asai T, Oku N, Araki Y, Tanka M, Ebihara N. Liposomes and nanotechnology in drug development: focus on ocular targets. Int $\mathrm{J} \mathrm{Na}$ nomedicine. New Zealand; 2013. p. 495-503.

52. Wong CW, Czarny B, Metselaar JM, Ho C, Ng SR, Barathi AV, et al. Evaluation of subconjunctival liposomal steroids for the treatment of experimental uveitis. Scientific Reports. 2018;8(1):6604.

53. Zhang R, Qian J, Li X, Yuan Y. Treatment of experimental autoimmune uveoretinitis with intravitreal injection of infliximab encapsulated in liposomes. Br J Ophthal. 2017;101(12):1731-8.

54. Tsai $\mathrm{CH}$, Wang PY, Lin IC, Huang H, Liu GS, Tseng CL. Ocular Drug Delivery: Role of Degradable Polymeric Nanocarriers for Ophthalmic Application. Inter J Molec Sci. 2018;19(9)

55. Alhalafi AM. Applications of polymers in intraocular drug delivery systems. Oman J Ophthalmol. 2017:10(1):3-8.

56. Mittal N, Kaur G. Investigations on Polymeric Nanoparticles for Ocular Delivery. Adv Polymer Tech. 2019;1316249.

57. Yavuz B, Pehlivan SB, Unlu N. Dendrimeric systems and their applications in ocular drug delivery. Sci World J. 2013;2013:732340.

58. Kambhampati SP, Kannan RM, Zarbin MA, Montemagno C, Leary JF, Ritch R, et al. Dendrimer nanoparticles for ocular drug delivery Nanomedicine for the treatment of retinal and optic nerve diseases Low molecular weight oligochitosans for non-viral retinal gene therapy Downregulation of VEGF mRNA expression by triamcinolone acetonide acetate-loaded chitosan derivative nanoparticles in human retinal pigment epithelial cells. I Ocul Pharmacol Ther. 2013;29(2):151-65.

59. Iezzi R, Guru BR, Glybina IV, Mishra MK, Kennedy A, Kannan RM. Dendrimer-based targeted intravitreal therapy for sustained attenuation of neuroinflammation in retinal degeneration. Biomaterials. 2012;33(3):979-88.

60. Kang SJ, Durairaj C, Kompella UB, O'Brien JM, Grossniklaus HE. Subconjunctival nanoparticle carboplatin in the treatment of murine retinoblastoma. Arch Ophthalmol (Chicago, III : 1960). 2009;127(8):1043-7.

61. Mandal A, Gote V, Pal D, Ogundele A, Mitra AK. Ocular Pharmacokinetics of a Topical Ophthalmic Nanomicellar Solution of Cyclosporine (Cequa(R)) for Dry Eye Disease. Pharma Res. 2019;36(2):36. 
62. Perini G, Saettone MF, Carafa M, Santucci E, Alhaique F. Niosomes as carriers for ophthalmic drugs: in vitro/in vivo evaluation. Bollettino Chimico farmaceutico. 1996;135(2):145-6.

63. Abdelkader $\mathrm{H}$, Alani AW, Alany RG. Recent advances in non-ionic surfactant vesicles (niosomes): self-assembly, fabrication, characterization, drug delivery applications and limitations. Drug Delivery. 2014;21(2):87-100.

64. Yadav KS, Rajpurohit R, Sharma S. Glaucoma: Current treatment and impact of advanced drug delivery systems. Life Sciences. 2019;221:362-76.

65. Khalil RM, Abdelbary GA, Basha M, Awad GE, El-Hashemy HA. Design and evaluation of proniosomes as a carrier for ocular delivery of lomefloxacin $\mathrm{HCl}$. J Lipo Res. 2017:27(2):118-29.

66. Battaglia L, Serpe L, Foglietta F, Muntoi E, Gallarate M, Del Pozo Rodriguez A, et al. Application of lipid nanoparticles to ocular drug delivery. Ex Opin Drug Delivery. 2016:13(12):1743-57.

67. Gan L, Wang J, Jiang M, Bartlett H, Ouyang D, Eperjesi F, et al. Recent advances in topical ophthalmic drug delivery with lipid-based nanocarriers. Drug Discov Today. 2013;18(5-6):290-7.

68. Han S, Shen JQ, Gan Y, Geng HM, Zhang XX, Zhu CL, et al. Nove vehicle based on cubosomes for ophthalmic delivery of flurbiprofen with low irritancy and high bioavailability. Acta Pharmacologica Sinica. 2010;31(8):990-8.

69. Huang J, Peng T, Li Y, Zhan Z, Zeng Y, Huang Y, et al. Ocular Cubosome Drug Delivery System for Timolol Maleate: Preparation, Characterization, Cytotoxicity, Ex Vivo, and In Vivo Evaluation. AAPS PharmSciTech. 2017:18(8):2919-26.

70. Hartnett TE, O'Connor AJ, Ladewig K. Cubosomes and other potentia ocular drug delivery vehicles for macromolecular therapeutics. Ex Opin Drug Delivery. 2015;12(9):1513-26.

71. Gan L, Han S, Shen J, Zhu J, Zhu C, Zhang X, et al. Self-assembled liquid crystalline nanoparticles as a novel ophthalmic delivery system for dexamethasone: Improving preocular retention and ocular bioavailability. Int J Pharm. 2010;396(1-2):179-87.

72. Cooper RC, Yang H. Hydrogel-based ocular drug delivery systems: Emerging fabrication strategies, applications, and bench-to-bedside manufacturing considerations. J Control Release. 2019;306:29-39.

73. Kirchhof S, Goepferich AM, Brandl FP. Hydrogels in ophthalmic applications. Eur J Pharm Biopharm. 2015;95(Pt B):227-38.

74. Jung HJ, Abou-Jaoude M, Carbia BE, Plummer C, Chauhan A. Glaucoma therapy by extended release of timolol from nanoparticle loaded silicone-hydrogel contact lenses. J Control Release. 2013;165(1):82-9.

75. Wu Z, Kong B, Liu R, Sun W, Mi S. Engineering of Corneal Tissue through an Aligned PVA/Collagen Composite Nanofibrous Electrospun Scaffold. Nanomaterials (Basel, Switzerland). 2018;8(2).

76. Myung D, Duhamel PE, Cochran JR, Noolandi J, Ta CN, Frank CW Development of hydrogel-based keratoprostheses: a materials perspective. Biotech Progress. 2008:24(3):735-41.

77. Zhan J, Singh A, Zhang Z, Huang L, Elisseeff JH. Multifunctional aliphatic polyester nanofibers for tissue engineering. Biomatter. 2012;2(4):202-12.

78. Gagandeep, Garg T, Malik B, Rath G, Goyal AK. Development and characterization of nano-fiber patch for the treatment of glaucoma. Eu J Pharm Sci. 2014;53:10-6.

79. Nagarwal RC, Kant S, Singh PN, Maiti P, Pandit JK. Polymeric nanoparticulate system: a potential approach for ocular drug delivery. J Contro Release. 2009;136(1):2-13.

80. Morrison PW, Khutoryanskiy VV. Advances in ophthalmic drug delivery Ther Delivery. 2014:5(12):1297-315.

81. Diebold $Y$, Calonge M. Applications of nanoparticles in ophthalmology. Progress Retin Eye Res. 2010;29(6):596-609.

82. Park K, Chen Y, Hu Y, Mayo AS, Kompella UB, Longeras R, et al. Nanoparticle-mediated expression of an angiogenic inhibitor ameliorates ischemia-induced retinal neovascularization and diabetes-induced retinal vascular leakage. Diabetes. 2009;58(8):1902-13.

83. del Pozo-Rodriguez A, Delgado D, Gascon AR, Solinis MA. Lipid nanoparticles as drug/gene delivery systems to the retina. J Ocul Pharmacol Ther. 2013;29(2):173-88

84. Lalu L, Tambe V, Pradhan D, Nayak K, Bagchi S, Maheshwari R, et al Novel nanosystems for the treatment of ocular inflammation: Curren paradigms and future research directions. J Control Release. Netherlands: 2017. Published by Elsevier B.V.; 2017. p. 19-39.
85. Balguri SP, Adelli GR, Majumdar S. Topical ophthalmic lipid nanoparticle formulations (SLN, NLC) of indomethacin for delivery to the posterior segment ocular tissues. European journal of pharmaceutics and biopharmaceutics : official journal of Arbeitsgemeinschaft fur Pharmazeutische Verfahrenstechnik eV. 2016;109:224-35

86. Zabihzadeh M, Rezaee H, Hosseini SM, Feghhi M, Danyaei A, Hoseini-Ghahfarokhi M. Improvement of dose distribution in ocular brachytherapy with (125)I seeds 20-mm COMS plaque followed to loading of choroidal tumor by gold nanoparticles. J Cancer Res Ther. 2019;15(3):504-11.

87. Wichterle O, Lim D, inventors; Cross-linked hydrophilic polymers and articles made therefrom. US1965.

88. Dubald M, Bourgeois S, Andrieu V, Fessi H. Ophthalmic Drug Delivery Systems for Antibiotherapy-A Review. Pharmaceutics. 2018;10(1).

89. Dixon $P$, Shafor C, Gause S, Hsu KH, Powell KC, Chauhan A. Therapeutic contact lenses: a patent review. Ex Op Ther Patents. 2015; 25(10):1117-29.

90. Guzman-Aranguez A, Fonseca B, Carracedo G, Martin-Gil A, Martinez-Aguila A, Pintor J. Dry Eye Treatment Based on Contact Lens Drug Delivery: A Review. Eye Contact Lens. 2016;42(5):280-8.

91. Maulvi FA, Patil RJ, Desai AR, Shukla MR, Vaidya RJ, Ranch KM, et al. Effect of gold nanoparticles on timolol uptake and its release kinetics from contact lenses: In vitro and in vivo evaluation. Acta Biomaterialia. 2019;86:350-62.

92. Yasin MN, Svirskis D, Seyfoddin A, Rupenthal ID. Implants for drug delivery to the posterior segment of the eye: a focus on stimuli-responsive and tunable release systems. J Control Release 2014:196:208-21.

93. Bernards D, Bhisitkul R, Deasi T. Zero-Order Sustained Drug Delivery to the Retina From a Nanoporous Film Device. On Drug Deliv Mag. 2014:48:20-1.

94. Lance KD, Good SD, Mendes TS, Ishikiriyama M, Chew P, Estes LS, et al. In Vitro and In Vivo Sustained Zero-Order Delivery of Rapamycin (Sirolimus) From a Biodegradable Intraocular Device. Invest Ophthalmol Visual Sci. 2015:56(12):7331-7.

95. Sharaf MG, Cetinel S, Heckler L, Damji K, Unsworth L, Montemagno C. Nanotechnology-Based Approaches for Ophthalmology Applications: Therapeutic and Diagnostic Strategies. Asia Pac J Ophthalmol (Phila). 2014;3(3):172-80.

96. Bachu RD, Chowdhury P, Al-Saedi ZHF, Karla PK, Boddu SHS. Ocular Drug Delivery Barriers-Role of Nanocarriers in the Treatment of Anterior Segment Ocular Diseases. Pharmaceutics. 2018;10(1).

97. De Campos AM, Sanchez A, Alonso MJ. Chitosan nanoparticles: a new vehicle for the improvement of the delivery of drugs to the ocular surface. Application to cyclosporin A. Int J Pharm. 2001;224(1-2):159-68.

98. Babizhayev MA. Coated with nanomaterials intraocular lenses, ophthalmic and human body implantable devices with high catalytic antioxidant activities: a new nanotechnology strategy of peroxidase cellular enzyme mimics increasing the biocompatibility and therapeutic deployment of the medical prosthetic device. Recent Pat Drug Deliv Formul. 2013;7(1):39-65.

99. Occhiutto ML, Maranhao RC, Costa VP, Konstas AG. Nanotechnology for Medical and Surgical Glaucoma Therapy-A Review. Adv Ther. 2020;37(1):155-99.

100. Badiee P, Varshochian R, Rafiee-Tehrani M, Abedin Dorkoosh F, Khoshayand MR, Dinarvand R. Ocular implant containing bevacizumab-loaded chitosan nanoparticles intended for choroidal neovascularization treatment. J Biomed Materials Res Part A. 2018;106(8):2261-71.

101. Huu VA, Luo J, Zhu J, Patel S, Boone A, Mahmoud E, et al. Light-responsive nanoparticle depot to control release of a small molecule angiogenesis inhibitor in the posterior segment of the eye. J Control Release. 2015;200:71-7.

102. Aleassa EM, Xing M, Keijzer R. Nanomedicine as an innovative therapeutic strategy for pediatric cancer. Ped Surg Inter. 2015;31(7):611-6.

103. $\mathrm{Kim} \mathrm{JH}, \mathrm{Kim} \mathrm{MH}$, Jo DH, Yu YS, Lee TG. The inhibition of retinal neovascularization by gold nanoparticles via suppression of VEGFR-2 activation. Biomaterials. 2011;32(7):1865-71.

104. Son M, Kim D, Park KS, Hong S, Park TH. Detection of aquaporin-4 antibody using aquaporin-4 extracellular loop-based carbon nanotube biosensor for the diagnosis of neuromyelitis optica. Biosensors ioelectronics. 2016;78:87-91.

105. Silva NC, Silva S, Sarmento B, Pintado M. Chitosan nanoparticles for daptomycin delivery in ocular treatment of bacterial endophthalmitis. Drug delivery. 2015;22(7):885-93. 